\title{
Relationship Between Job Satisfaction and Positive Affect on Turnover Intention (Study in Non-Bank Financing Institutions in Ternate City, Indonesia
}

\author{
Abdullah W. Jabid ${ }^{1}$, Johan Fahri ${ }^{2}$, Irfandi Buamonabot ${ }^{3}$, Muhammad Asril \\ Arilaha $^{4}$ \\ \{abdullah.jabid@unkhair.ac.id ${ }^{1}$, johan.fahri@unkhair.ac.id ${ }^{2}$, rfandibbot@gmail.com³ \\ asril_arilaha@unkhair.ac.id ${ }^{4}$ \\ Faculty of Economics and Business, Khairun University ${ }^{1,2,4}$ \\ Politeknik Sains \& Teknologi Wiratama, Maluku Utara ${ }^{3}$
}

\begin{abstract}
Despite the extensive literature on job satisfaction, inconsistencies are still found reality. In this constantly changing environment, organizations concern about their valuable workers who deciding to leave the job and move to another competitor while bringing all the knowledge and experience. Organizations therefore strive to retain their human resource assets to ensure that they can still contribute to achievement of strategic objectives. They more efforts on improving and fostering job satisfaction and positive effect, so the employees would not have intention to leave and lead to workers' turnover. This study was then conducted to re-examining the relationship of job satisfaction and positive effect on turnover intention. A total of 88 non-bank financial institution employees were collected through a survey and analyzed using regression analysis. The results of testing two hypotheses show that each hypothesis is supported and not supported in this study.
\end{abstract}

Keyword: Job Satisfaction, Positive Affect, Turnover Intention

\section{Introduction}

Workers are said to be an important part of the organization so satisfied with the job is said to be the important factor that leads to the intention of leaving. Turnover is affected by the attitude of workers; it could have a positive or a negative impact both in the industry [1]. Employee turnover has been viewed as an important organizational problem. Its importance lies in the fact that there are numerous negative consequences in organizations if the rate of employee turnover is high. The direct and indirect costs associated with turnover, not only in terms of recruitment and training but also in terms of work disruption and demoralization of remaining employees, are very significant and expensive [2].

Turnover intention is a predictor for predicting turnover [3],[4],[5],[6]. Mobley [3] defines turnover intention, which refers to the desire to leave the work preceded by an evaluation of the current job, the emergence of a sense of satisfaction or dissatisfaction with the current job, the calculation of costs and benefits, and ends with a decision to survive or quit.

Among various factors influencing the intentions of a person to quit the job, job satisfaction has been found to be the most influential [2]. Job satisfaction is a happy emotional 
state or positive emotions that come from the assessment of one's work or work experience [7]. The results of the study linking job satisfaction and turnover intention showed negative results [8],[9],[10], and positive affect also showed negative results [11]. Based on this, the design of this study reexamined the relationship between job satisfaction and positive effect on turnover intention. In addition, the use of positive affect variables in this study for Indonesia is still rare.

\section{Literature Review and Hypotheses}

Job satisfaction is a happy emotional state or positive emotions that come from the assessment of one's work or work experience [7]. Cetin [12] explains that job satisfaction is a person's reaction to a job or organization.

Turnover intention is a predictor for predicting turnover. Mobley [3] defines turnover intention, which refers to the desire to leave the work preceded by an evaluation of the current job, the emergence of a sense of satisfaction or dissatisfaction with the current job, the calculation of costs and benefits, and ends with a decision to survive or quit. Whereas Jaros [13] defines turnover intention refers to the tendency of employees to stop being part of organizational membership.

The effect is a word used to describe the state of one's internal feelings [14]. A person's circumstances are implicitly and explicitly against an object, person or position tends to be regarded as evaluative judgments than an internal condition feeling person. Positive Affect is defined as an affective personality trait that represents a predisposition or readiness to respond positively to environmental stimuli [15].

Mobley [3] argues that job dissatisfaction translates into the thought of quitting in the hope that quitting will ultimately result in more satisfying work. An employee always wants satisfaction at work. However, employees do not always get the desired job satisfaction. This is due to the work atmosphere that is not conducive, feel the work is never finished, thus employees feel anxious, not excited, cannot enjoy the work, and are not comfortable with the current job, when this happens it will have an impact on decreasing satisfaction with the job so that conditions like this will result in employees to make an intention to leave. The results showed that the relationship between job satisfaction and turnover intention had a negative relationship [8],[9],[10].

\section{Hypothesis 1: job satisfaction has a negative effect on turnover intention}

Positive Affect is defined as an affective personality trait that represents a predisposition readiness to respond positively to environmental stimuli [15]. The relationship between positive affect and turnover intention is negative[16]. Individuals who have high positive traits tend to be more willing to change their situation when they feel dissatisfied. Furthermore, the relationship between job satisfaction and turnover intention is the one who feels the strongest among people who feel that their values are not fulfilled at work and tend to experience high positive moods. This is certainly when feeling higher self- achievement in terms of skills and ability to find new jobs that will fulfill their value [17]. 
Hypothesis 2: Positive affect affects the intention to leave.

\section{Research Method}

From the various studies above, it can be assumed that job satisfaction has a negative effect on turnover intention and positive affect also has a negative effect on the intention to leave. To facilitate an understanding of the relationship between the various variables, Figure 1 presents the research model.

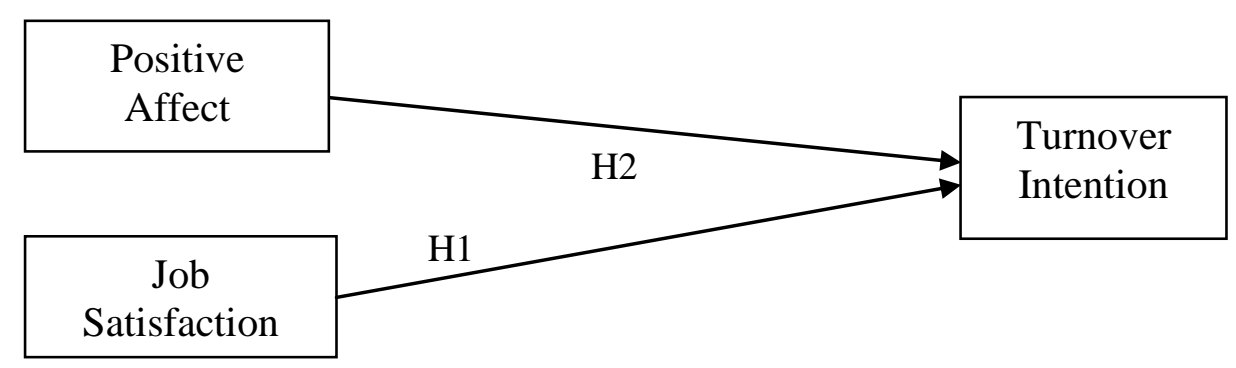

Fig. 1. Model

The design of this study is hypothesis testing, with survey methods. Data collection in this study was carried out by a cross-sectional method that is collecting or retrieving data at a certain time [18].

The population in this study is non-banking employees who work in the city of Ternate. The sample size used in this study was 88 respondents. The sample used in this study will be taken with a non-probability sampling method, namely purposive sampling with a judgment sampling approach, which involves selecting subjects who are in the most advantageous place or in the best position to provide the information needed [19]. Purposive sampling is chosen based on the consideration that employees of non- bank financial institutions are more burdened on the company's target without being followed by the level of welfare, so this will certainly have an impact on high turnover intention.

The data used in this study were collected by a survey method using a questionnaire. Surveys are an appropriate method for research questions regarding the beliefs or behavior of someone reported [18].

Validity is the level at which a test measures what it really wants to be measured. The items used in this study are those that have a factor loading value $\geq 0.5$ [20] Reliability is related to the accuracy and precision of a measurement procedure [21]. In this study, the reliability test was carried out by looking at Cronbach's Alpha values above 0.7 [20]. Hypothesis 1 and 2 testings are done using simple regression analysis [20].

Job satisfaction is a happy emotional state or positive emotions that come from the assessment of one's work or work experience [7]. Job satisfaction was measured by using a 
5 item statement developed by Brayfield and Rothe [7], which uses a Likert scale with one strongly disagree to 5 strongly agree. For example: "I really enjoy my work".

Turnover intention is defined as the conscious and deliberate willingness to leave the organization [13]. The turnover intention was measured by using three items of the statement, which was developed by Irving, [22], using a Likert scale with one very disagree to 5 strongly agree. For example: "I want to stay with my current job for the future".

Positive Affect is defined as an affective personality trait that represents a predisposition or readiness to respond positively to environmental stimuli [15]. Positive affect is measured by using 4 item statements developed by [23], who use a Likert scale with one strongly disagreeing to 5 strongly agreeing. For example: "I feel enthusiastic at work".

\section{Result and Discussion}

Respondents in this study are employees who work at non-bank financial institutions in Ternate. Based on the results of the questionnaire distribution, a total of 115 was distributed in this study. Of the $102(88.70 \%)$ questionnaires returned, only $88(76.52 \%)$ questionnaires were declared eligible for analysis in the framework of hypothesis testing. Thus the response rate in the study was $85 \%$.

Respondent characteristics used in this study include age, sex, last education, marital status, current position, and working age. In general, the majority of respondents were male ( 56 a tau by $64 \%$ ) and women ( 32 or $36 \%$ ), with an average age of 39 years, and most of the educational level is graduates Tier $1(89 \%)$.

Table 1 presents the results of factor analysis to test the validity of statement items that measure job satisfaction, positive affect, and turnover intention. No statement items are discarded because everything has a loading factor in the above 0.5. The same is true for the reliability test results in that all variables are declared reliable with Cronbach's alpha values above 0.7 .

Table 1. Test Results Validity and Reliability

\begin{tabular}{cccc}
\hline Factor and Scales & Factor 1 & Factor 2 & Factor 3 \\
JS $=$ Job Satisfaction $=$ & Cronbach $\alpha: 0.812$ & \\
JS 1 & 0.862 & \\
JS 2 & 0.658 & \\
JS 3 & 0.827 & \\
JS 4 & 0.764 & \\
JS 5 & 0.662 & \\
PA $=$ Positive Affect $=$ Cronbach $\alpha: 0.814$ & \\
PA 1 & & 0.813 \\
PA 2 & 0.784 \\
\hline
\end{tabular}




\begin{tabular}{|c|c|c|c|}
\hline Factor and Scales & Factor 1 & Factor 2 & Factor 3 \\
\hline PA3 & & 0.877 & \\
\hline PA4 & & 0.735 & \\
\hline \multicolumn{4}{|c|}{$\mathrm{TI}=$ Turnover Intention $=$ Cronbach $\alpha: 0.854$} \\
\hline TI1 & & & 0.840 \\
\hline TI2 & & & 0.843 \\
\hline TI3 & & & 0.954 \\
\hline
\end{tabular}

Based on table 2, the average value of job satisfaction is quite low, which is 2.30. The low figure job satisfaction indicates that respondents have job satisfaction are low. The average value for the positive effect variable shows a fairly high number that is equal to 4.04 . The high number of positive affect shows that the respondent has a high positive affect/good. While the average value of turnover intention of 3.52. The average value of the turnover intention shows a tendency that respondents perceive a high enough turnover intention.

Table 2. Mean, Maximum, Minimum and Standard Deviation

\begin{tabular}{lcccc}
\hline \multicolumn{1}{c}{ VARIABLE } & M & SD & MAX & MIN \\
\hline Job Satisfaction & 2.30 & 0.31 & 4.00 & 2.00 \\
Positive Affect & 4.04 & 0.69 & 5.00 & 1.00 \\
Turnover Intention & 4.02 & 0.41 & 4.67 & 2.67 \\
\hline
\end{tabular}

Based on the results of the hypothesis test shown in table 2 that job satisfaction has a significant negative effect on turnover intention $(\beta=-0.175 \mathrm{t}=-2.432, \mathrm{P}<0.05)$ and positive affect does not significantly influence positive turnover intention $(\beta=0.105 \mathrm{t}=1.510, \mathrm{P}>0.05)$.

Table 3. Hypothesis Testing Results

\begin{tabular}{cccc}
\hline \multirow{2}{*}{ Independent Variable } & \multicolumn{3}{c}{ Turnover Intention } \\
\cline { 2 - 4 } & $\mathbf{B}$ & $\mathbf{t}$ & $\mathbf{P .}$ Val \\
\hline Job Satisfaction & -0.175 & -2.432 & $0.017^{*}$ \\
Positive affect & 0.105 & 1.510 & 0.135 \\
\hline
\end{tabular}

The results showed that turnover intention is influenced by job satisfaction. Thus hypothesis 1 is supported. The results of this study are in accordance with the theory put forward by Mobley. According to Mobley [3], turnover intention refers to the desire to quit his job. The turnover intention process is preceded by an evaluation of the current job so that it creates a sense of satisfaction or dissatisfaction with the current job. Satisfaction or dissatisfaction will be preceded by how much the calculation of costs and benefits. If the costs and benefits to be obtained are greater than the current job, then it will end with an exit decision. Conversely, if the costs and benefits to be obtained are smaller than the current job, then it will end with a decision to survive [3]. The results of this study are also supported by 
[8],[9],[10] that job satisfaction has a negative effect on turnover intention.

The results of this study do not support the hypothesis that Positive Affect Air relations negatively with turnover intention. The results of this study are not in accordance with the theory put forward by Weitz [24]. According to Weitz positive affect is a variable that must be considered in relation to the relationship between job satisfaction and negative turnover intention.

\section{Conclusion}

This study aims to examine the relationship of job satisfaction on turnover intention and positive effect on turnover intention. Based on the results of simple regression analysis and discussion, it can be concluded that job satisfaction has a negative effect on turnover intention and positive affect has no effect on turnover intention. Future studies should try the positive effect variable as a moderating relationship between job satisfaction and turnover intention.

\section{References}

[1] Alam, A. and Asim, M.: "Relationship Between Job Satisfaction and Turnover Intention," Int. J. Hum. Resour. Stud., vol. 9, no. 2, pp. 163-194 (2019)

[2] Randhawa, G "Relationship between job satisfaction and turnover intentions: An empirical analysis,” Indian Manag. Stud. J., vol. 11, no. 2, pp. 149-159 (2007)

[3] Mobley, W. H.: "Intermediate linkages in the relationship between job satisfaction and employee turnover.," J. Appl. Psychol., vol. 62, no. 2, p. 237 (1977)

[4] Michaels, C. E. and Spector, P. E.: "Causes of employee turnover: A test of the Mobley, Griffeth, Hand, and Meglino model.,” J. Appl. Psychol., vol. 67, no. 1, p. 53 (1982)

[5] Mobley, W. H., Horner, S. O.: and A. T. Hollingsworth, "An evaluation of precursors of hospital employee turnover.," J. Appl. Psychol., vol. 63, no. 4, p. 408 (1978)

[6] Fishbein, M. and Ajzen, I.: "Attitudes towards objects as predictors of single and multiple behavioral criteria.," Psychol. Rev., vol. 81, no. 1, p. 59 (1974)

[7] Brayfield, A. H., and Rothe, H. F.: "An index of job satisfaction.," J. Appl. Psychol., vol. 35, no. 5, p. 307 (1951)

[8] Ali, N. and Baloch, Q. B.: "Impact of job satisfaction on turnover intention: An empirical evidence,” J. Manag. Sci., pp. 23-41 (2008)

[9] Aydogdu, S. and Asikgil, B.: "An empirical study of the relationship among job satisfaction, organizational commitment and turnover intention," Int. Rev. Manag. Mark., vol. 1, no. 3, p. 43, (2011)

[10] Gamage, M. S. P. N., and Buddhika, M.: "Job satisfaction and intention to leave of IT professionals in Sri Lanka,” Asia Pacific J. Mark. Manag. Rev. ISSN, vol. 2319, p. 2836 (2013)

[11] Shaw, J. D.: "Job satisfaction and turnover intentions: The moderating role of positive affect," J. Soc. Psychol., vol. 139, no. 2, pp. 242-244 (1999)

[12] Cetin, M. O.: "The relationship between job satisfaction, occupational and organizational commitment of academics," J. Am. Acad. Bus., vol. 8, no. 1, pp. 78-88 (2006)

[13] Jaros, S. J.: "An assessment of Meyer and Allen's (1991) three-component model of organizational commitment and turnover intentions," J. Vocat. Behav., vol. 51, no. 3, pp. 319-337 (1997)

[14] Cohen, J. B., Pham, M. T. and Andrade, E. B.: "The nature and role of affect in consumer behavior," Handb. Consum. Psychol., vol. 4, pp. 297-348 (2008) 
[15] Cropanzano, R., James, K., and Konovsky, M. A.: "Dispositional affectivity as a predictor of work attitudes and job performance," J. Organ. Behav., vol. 14, no. 6, pp. 595-606 (1993)

[16] Barsade, S. G., and Gibson, D. E.: "Why does affect matter in organizations?," Acad. Manag. Perspect., vol. 21, no. 1, pp. 36-59 (2007)

[17] George, J. M., and Jones, G. R. "The experience of work and turnover intentions: Interactive effects of value attainment, job satisfaction, and positive mood.," J. Appl. Psychol., vol. 81, no. 3, p. 318 (1996)

[18] Neuman,V.: Human social research method, Sixth edit. Sydney: Pearson Education (2006)

[19] Sekaran, U.: "Research methods for business 4th edition. Hoboken." NJ: John Wiley \& Sons, (2009)

[20] Hair, J. F., Black, W. C., Babin, B. J., Anderson, R. E., and Tatham, R. L.: Multivariate data analysis, vol. 5, no. 3. Prentice hall Upper Saddle River, NJ (1998)

[21] Kombo, R and Tromp, S.: "Business Research Methods 10thedition." McGraw-Hill Publications. New York, United States (2009)

[22] Irving, P. G., Coleman, D. F., and Cooper, C. L.: "Further assessments of a three-component model of occupational commitment: Generalizability and differences across occupations.," J. Appl. Psychol., vol. 82, no. 3, p. 444 (1997)

[23] Laroche, M., Babin, B. J., Lee, Y., Kim, E., and Griffin, M.: "Modeling consumer satisfaction and word-of-mouth: restaurant patronage in Korea," J. Serv. Mark (2005)

[24] Weitz, J.: "A neglected concept in the study of job satisfaction," Pers. Psychol., vol. 5, no. 3, pp. 201-205 (1952) 